\title{
IMPROVEMENT OF URINARY $\delta$-AMINOLEVULINIC ACID DETERMINATION BY HPLC AND FLUORESCENCE DETECTION USING CONDENSING REACTION WITH ACETYLACETONE AND FORMALDEHYDE
}

\author{
Yoko Endo, ${ }^{* 1}$ Akira Orayama, ${ }^{* 2}$ Ginji Endo, ${ }^{* 3}$ Teruko Ueda, ${ }^{* 1}$ \\ Naoki NAKAZONO*1 and Shun'ichi HoRIGUCHI ${ }^{* 3}$
}

\begin{abstract}
We improved the method for determining urinary $\delta$-aminolevulinic acid (ALA) by HPLC-fluorometer after pre-column derivatization with acetylacetone and formaldehyde, and a stable ALA derivative was obtained without any effect from various urinary components as demonstrated by the complete recovery of ALA $(100.9 \pm 5.5 \%, n=85)$ from the urine samples. The modified procedure was as follows: Twenty $\mu \mathrm{l}$ of urine sample, $5 \mathrm{ml}$ of acetylacetone solution (acetylacetone/ethanol/distilled water containing $4 \mathrm{~g} / \mathrm{l}$ of $\mathrm{NaCl} ; 15 / 10 / 75$ ), and $0.45 \mathrm{ml}$ of $9.3 \%$ formaldehyde solution were mixed and boiled for 15 min. The fluorescent derivative of ALA was separated and analyzed by HPLC with the fluorometer at Ex $246 \mathrm{~nm}$ and $\mathrm{Em} 458 \mathrm{~nm}$. Using a gradient program, the retention time of the ALA derivative was $7.3 \mathrm{~min}$ and the analysis could be repeated at $13 \mathrm{~min}$ intervals. Concentrations of ALA in urine samples measured by this method were significantly correlated with those measured by the Mauzerall-Granick (M-G) method $(n=85, r=0.993, p<0.001)$. The values obtained by our method were, however, lower than those obtained by the M-G method. Urinary ALA concentrations of 40 non-lead workers ranged from 0.1 to $2.3 \mathrm{mg} / \mathrm{g}$ creatinine with the mean $\pm \mathrm{SD}$ of $1.1 \pm 0.4 \mathrm{mg} / \mathrm{g}$ creatinine as measured by the present method.

Key words: lead; urine; $\delta$-aminolevulinic acid; HPLC; fluorometry; pre-column; formaldehyde; acetylacetone
\end{abstract}

\section{INTRODUCTION}

Recently, some new analytical procedures ${ }^{1-5)}$ for measuring $\delta$-aminolevulinic acid (ALA) in urine have been reported which can measure a large number of samples simpler and more accurately than by the conservative colorimetric methods. Among these procedures, ${ }^{1-5}$ ) the fluorometric HPLC method devised by Okayama et al.2) (Okayama method) has the lowest detection limit and a wide range of linearity of $0.25-100$ $\mathrm{mg} / l$, and is suitable for automated analysis. However, as shown in our previous short com-

*1 Department of Public Health, Kansai Medical University

*2 Department of Health Science, Shiga University of Medical Science

*3 Department of Preventive Medicine and Environmental Health, Osaka City University Medical School

Received for publication, May 19, 1993 munication, ${ }^{6}$ ) this method has some weak points in that the recovery rate of ALA from urine is relatively low and the recovery decreases with elevation of specific gravity of the urine.

Generally, the intensity of fluorescence is strongly affected by the components, analytical temperature, and other factors. However, when the worker's urine was checked by the HPLC method, the effect from co-existing substances was not theoretically significant because of the isolation of the ALA derivative. The thermal effect was also negligible because there was no space between the fluoreometer and the column oven.

It was presumed that co-existing substances interfered with ALA derivatization. Therefore, we studied the effect of urinary components on the reaction rate of the ALA derivatization in order to establish the optimum conditions for obtaining a recovery rate of more than $90 \%$ of all urine samples in this procedure. A summary 
of this method has been previously reported in a short communication. ${ }^{6}$ This report describes in detail the interference from urinary co-existent substances and the optimization of the conditions.

The ALA values obtained by this method were compared with those obtained by the MauzerallGranick (M-G) method, and the differences between the two methods were discussed. The normal range of urinary ALA concentrations by the fluorometric HPLC method was also described.

\section{MATERIALS AND METHODS}

The subjects were 45 male workers with moderate exposure to lead in a secondary lead refinery and 40 male pest control workers engaged in exterminating rats without occupational exposure to lead. The mean age of the 45 lead workers was $51.7 \pm 13.2 \mathrm{yr}$, and that of the 40 pest control workers was $43.5 \pm 11.2$ yr. The blood lead concentration was $458 \pm 273 \mu \mathrm{g} / \mathrm{l}$ (mean $\pm \mathrm{SD}$; range $46-1,030 \mu \mathrm{g} / l)$ for the lead workers and $47 \pm 16 \mu \mathrm{g} / l$ (mean $\pm \mathrm{SD}$; range 18-93 $\mu \mathrm{g} / l$ ) for the pest control workers.

After measuring urine specific gravity and creatinine, the urine samples were centrifuged at $1,000 \mathrm{G}$ for $10 \mathrm{~min}$ and kept at $-20^{\circ} \mathrm{C}$ until the HPLC analysis was performed. The ALA in the urine of all workers was also measured by the M-G method. ${ }^{7)}$ The modified HPLC method was as follows: Twenty $\mu \mathrm{l}$ of urine or ALA standard solution, $5 \mathrm{ml}$ of acetylacetone solution (acetylacetone/ethanol/distilled water containing 4 $\mathrm{g} / \mathrm{l}$ of $\mathrm{NaCl} ; 15 / 10 / 75, \mathrm{v} / \mathrm{v}$ ), and $0.45 \mathrm{ml}$ of $9.3 \%$ formaldehyde solution were put into a screw cap tube, mixed, boiled for $15 \mathrm{~min}$, and cooled under water. Fifty microliters of the solution was injected into the HPLC system through an auto sampler (AS-8000, Tosoh, Japan), in which the sample was kept in the dark at $15^{\circ} \mathrm{C}$. The injected sample was then separated through an octadecyl silica (ODS) column (TSK-80 TM, $\phi$ $4.6 \times 150 \mathrm{~mm}, 5 \mu \mathrm{m}$ particles, Tosoh, Japan) at $40^{\circ} \mathrm{C}$, and eluted gradiently with two solutions (A) and (B) as shown in Fig. 1. Solution (A) consisted of acetonitrile, methanol, acetic acid and distilled water $(100: 350: 10: 540, \mathrm{v} / \mathrm{v})$. Solution (B) consisted of $100 \%$ acetonitrile. The fluorescence intensity was measured at $458 \mathrm{~nm}$ with excitation

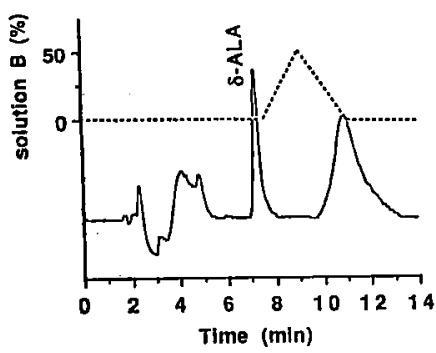

Fig. 1. Schematic diagram of gradient elution and a typical chromatogram for $50 \mu \mathrm{l}$ injection of ALA standard solution $(1.5 \mathrm{mg} / l)$.

at $246 \mathrm{~nm}$ in a spectrofluorometer (HP 1046A, Hewlett-Packard, U.S.A.).

ALA hydrochloride (Sigma, U.S.A.) was dissolved in distilled water to give a concentration of $109.6 \mathrm{mg}$ of ALA per liter and used as a stock solution. Methanol and acetonitrile were of the HPLC-grade (Wako Pure Chem., Japan), and the other chemicals were of the reagent-grade (Wako Pure Chem., Japan).

\section{RESULTS}

A typical chromatogram of the standard ALA solution and the gradient program of the mobile phase are shown in Fig. 1. The ALA derivative was eluted for $7.3 \mathrm{~min}$. Using the gradient program, continuous analysis every $13 \mathrm{~min}$ with an auto-sampler could be carried out without elevation of the column pressure.

Since the recovery rate of ALA by the Okayama method $^{2)}$ was not satisfactory, we examined the reaction under various conditions to obtain the highest reaction rate and the most stable derivative. Firstly, the reaction was performed under various concentrations of formaldehyde, but the volume of each solution in the mixture was the same as that of the Okayama method. The highest reaction rate was obtained when $9.3 \%$ formaldehyde solution was used, and the rate was twice of that obtained by the Okayama method $(3.1 \%$ formaldehyde solution) as shown in Table 1 . When $37 \%$ of formaldehyde solution was used as a reagent, many peaks were detected by the fluorometer and they were eluted earlier than the expected ALA derivative as shown in Fig. 2. When $0.45 \mathrm{ml}$ of $9.3 \%$ formaldehyde solution was used and various volumes $(2-7 \mathrm{ml})$ of the acetylacetone solution were tested, the highest reaction rate was 
Table 1. Effect of formaldehyde concentration on ALA derivatization.

\begin{tabular}{cccc}
\hline Formaldehyde conc. & Peak area & Ratio & FA/AA ratio \\
\hline $3.1 \%$ & 510,933 & 1.00 & 0.027 \\
4.6 & 823,121 & 1.61 & 0.039 \\
9.3 & 960,364 & 1.88 & 0.080 \\
18.5 & 494,166 & 0.97 & 0.159 \\
37.0 & 123,320 & 0.24 & 0.317 \\
\hline
\end{tabular}

Reaction was performed by mixing and boiling for $15 \mathrm{~min}$. The reaction mixture consisted of $50 \mu l$ of $5.5 \mathrm{mg} / \mathrm{l}$ of standard solution, $3.5 \mathrm{ml}$ of the acetylacetone solution and $0.45 \mathrm{ml}$ of the various concentrations of formaldehyde solution. Fifty microliters of the mixture was injected into the HPLC system. FA/AA ratio expresses (final formaldehyde concentration)/(final acetylacetone concentration).

Table 2. Effect of various volumes of acetylacetone solution on ALA derivatization.

\begin{tabular}{ccccc}
\hline $\begin{array}{c}\text { Acetylacetone } \\
(\mathrm{ml})\end{array}$ & Peak area & $\begin{array}{c}\text { Ratio } \\
(\%)\end{array}$ & $\begin{array}{c}\text { Total vol } \\
(\mathrm{ml})\end{array}$ & $\begin{array}{c}\text { FA/AA } \\
\text { ratio }\end{array}$ \\
\hline 2.0 & $3,239,478$ & 62.4 & 2.47 & 0.140 \\
3.5 & $3,231,968$ & 100.0 & 3.97 & 0.080 \\
5.0 & $2,391,355$ & 101.9 & 5.47 & 0.056 \\
7.0 & $1,601,926$ & 93.3 & 7.47 & 0.040 \\
\hline
\end{tabular}

Reaction was performed by mixing and boiling for $15 \mathrm{~min}$. The reaction mixture consisted of $20 \mu 1$ of the 55.0 $\mathrm{mg} / \mathrm{l}$ standard solution, various volume of the acetylacetone solution and $0.45 \mathrm{ml}$ of $9.3 \%$ formaldehyde solution. Fifty microliters of the mixture was injected into the HPLC system. FA/AA ratio expresses (final formaldehyde concentration)/(final acetylacetone concentration).

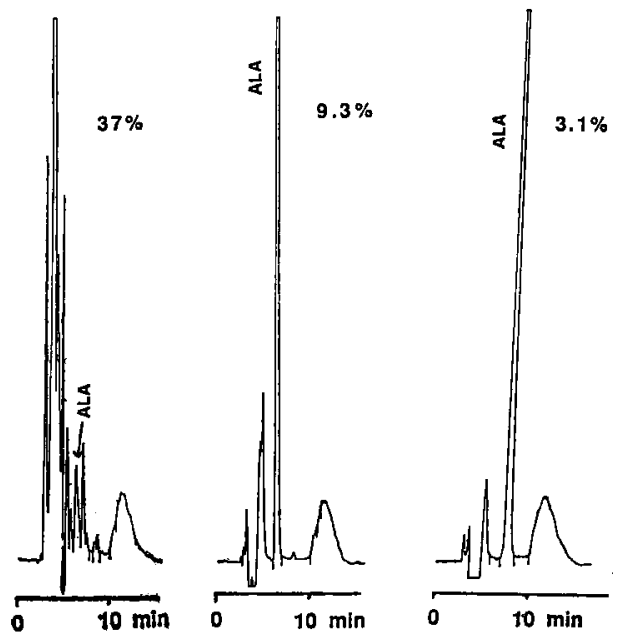

Fig. 2. Chromatograms of ALA derivatives prepared with $0.45 \mathrm{ml}$ solution of several formaldehyde concentrations $(37,9.3,3.1 \%)$.

found between 3.5 and $5.0 \mathrm{ml}$ of the acetylacetone solution, as shown in Table 2. When $0.45 \mathrm{ml}$ of

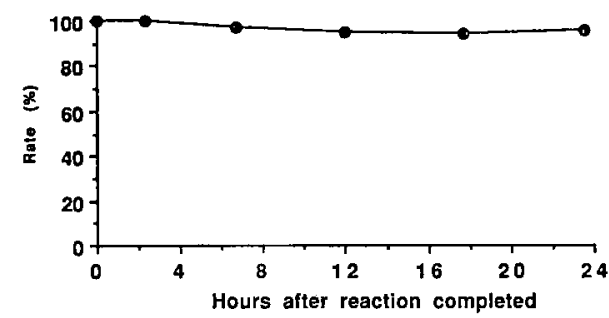

Fig. 3. Stability of ALA derivative made from ALA standard solution $(11 \mathrm{mg} / l)$.

$9.3 \%$ formaldehyde solution and $5 \mathrm{ml}$ of acetylacetone solution were used for the reaction, the stability of the ALA derivative was very good as shown in Fig. 3. The decline was below 5\% during $24 \mathrm{~h}$ in the dark at $15^{\circ} \mathrm{C}$. When the sample was stored in a refrigerator with a glass door (MEDICOOL, SANYO, Japan) at $3^{\circ} \mathrm{C}$ for $24 \mathrm{~h}$, the decrease was below $3 \%$ (data not shown). The within-day and between-day coefficients of variation were $1.1 \%(n=5)$ and $1.4 \%(n=5$ for two days) for $7.6 \mathrm{mg} / l$ of ALA in an urine sample, 


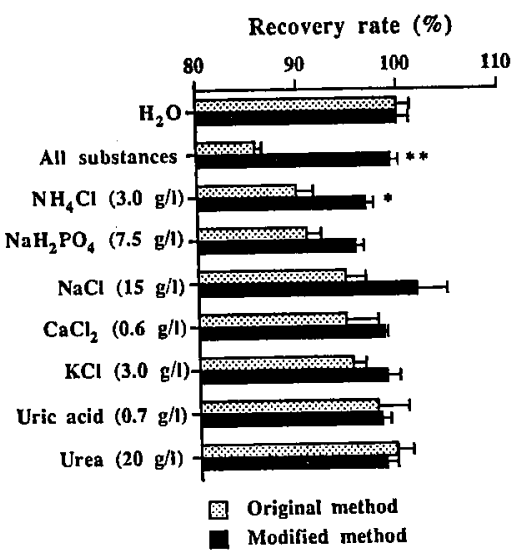

Fig. 4. Effects of various substances on ALA derivatization using original method and the modified method. Original method: $50 \mu \mathrm{l}$ of standard solution containing the urinary component, $0.45 \mathrm{ml}$ of $3.1 \%$ formaldehyde solution, and $3.5 \mathrm{ml}$ acetylacetone solution. Modified method: $20 \mu \mathrm{l}$ of standard solution containing the urinary component, $0.45 \mathrm{ml}$ of $9.3 \%$ formaldehyde solution, and $5.0 \mathrm{ml}$ acetylacetone solution. "All" means addition of all the urinary components of $\mathrm{NaCl}, \mathrm{KCl}, \mathrm{CaCl}_{2}$, urea, $\mathrm{NaH}_{2} \mathrm{PO}_{4}, \mathrm{NH}_{4} \mathrm{Cl}$ and uric acid. * significantly different from the original method, $p<0.05$. ** significantly different from original method, $p<0.001$.

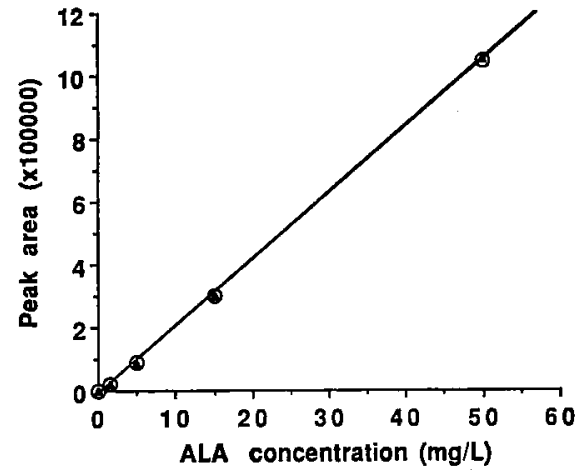

Fig. 5. Calibration curve of ALA standard with (A) or without (O) various substances in urine the concentrations of which are shown in Fig. 4.

respectively.

In order to study the effects of various urinary co-extisting substances on ALA derivatization, we used the upper limit concentration of the normal urinary components in the Japanese people, ${ }^{8)}$ such

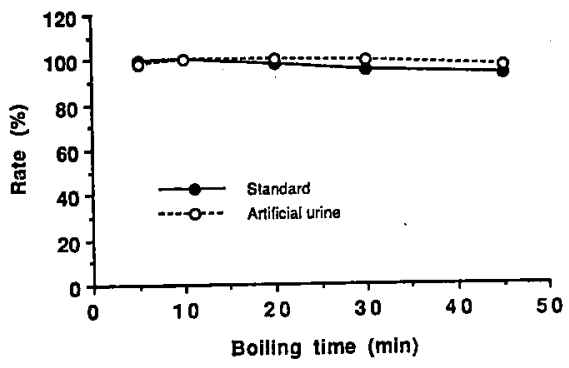

Fig. 6. Effect of boiling time on ALA derivatization. - , aqueous ALA standard; $O$, aqueous ALA standard with various urinary components the concentrations of which are shown in Fig. 4.

as $15 \mathrm{~g} / l$ of $\mathrm{NaCl}, 3.0 \mathrm{~g} / l$ of $\mathrm{KCl}, 0.6 \mathrm{~g} / l$ of $\mathrm{CaCl}_{2}$, $20 \mathrm{~g} / l$ of urea, $7.5 \mathrm{~g} / l$ of $\mathrm{NaH}_{2} \mathrm{PO}_{4}, 3.0 \mathrm{~g} / l$ of $\mathrm{NH}_{4} \mathrm{Cl}$ or $0.7 \mathrm{~g} / l$ of uric acid. Effects of the components added to the ALA standard solution on the recovery rate is shown in Fig. 4. Serious negative effects of $\mathrm{NaH}_{2} \mathrm{PO}_{4}$ and $\mathrm{NH}_{4} \mathrm{Cl}$ were found in the Okayama method, but not in the modified method.

Figure 5 shows the calibration curves made from the ALA standard and the addition of all the components to the ALA standard solution. Both calibration curves showed complete agreement.

The relationship between the reaction rate of ALA derivatization and the boiling time is shown in Fig. 6. The highest reaction rate was obtained during 10-20 min of heating. In the standard solution containing all the components, no significant decrease was found from 5 to $45 \mathrm{~min}$.

When urine samples from 45 lead workers were measured by the present method, the ALA concentration ranged from 0.4 to $72.4 \mathrm{mg} / \mathrm{l}$. These values were well correlated with those by the Okayama method, but the values by the Okayama method (y) were $70 \%$ of those found by our method $(x)(y=0.691 x+0.114, n=45, r=0.969$, $p<0.01)$. Recovery rates of ALA $(n=45)$ obtained by adding 1-2 times the amount of the urinary ALA concentrations were $84.6+7.6 \%$ by the Okayama method and $101.3 \pm 5.5 \%$ by our method. When measured by the Okayama method, the recovery rate significantly decreased with increase in specific gravity of the urine $(n=45$, $r=-0.306, p=0.0412$ ). Neither the urinary creatinine concentration nor the specific gravity of 
Table 3. ALA concentration (mg/g creatinine) of workers.

\begin{tabular}{lcc}
\hline Methods & $\begin{array}{c}\text { Lead workers } \\
(n=45)\end{array}$ & $\begin{array}{c}\text { Non-lead workers } \\
(n=40)\end{array}$ \\
\hline HPLC & $6.9 \pm 14.0$ & $1.1 \pm 0.4$ \\
(range) & $(0.6-85.2)$ & $(0.1-2.3)$ \\
M-G & $8.3 \pm 13.7$ & $2.1 \pm 0.5$ \\
(range) & $(1.5-83.4)$ & $(1.2-3.1)$ \\
\hline
\end{tabular}

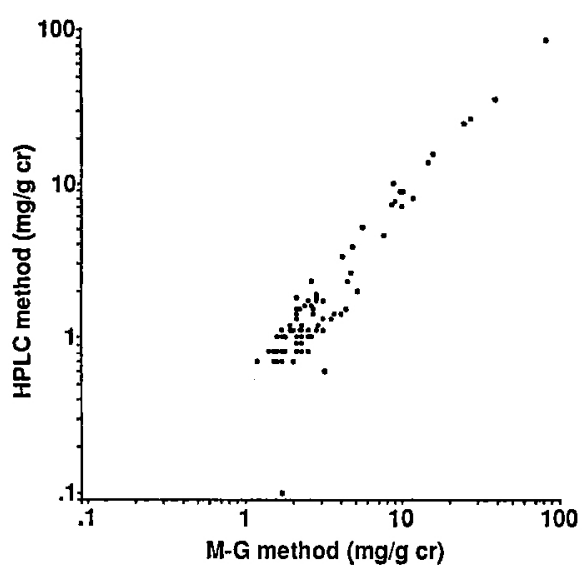

Fig. 7. Relation between ALA concentrations (mg/g creatinine) by the M-G method $(X)$ and those by the modified HPLC $(Y)$. $\log Y=1.241$ $\log X-0.39(n=85, r=0.997, p<0.001)$.

the urine correlated with the recovery rate by our method. There was a significant positive correlation between the ALA concentrations by the M-G method $(x \mathrm{mg} / l)$ and those by our method (y $\mathrm{mg} / l)(y=1.005 x-1.668, n=45, r=0.991, p<$ 0.001). However, the concentrations by our method were lower than those by the M-G method among more than $95 \%$ of the samples.

When urine samples from 40 control workers were measured by the present method, ALA concentrations ranged from 0.4 to $3.9 \mathrm{mg} / l(1.2 \pm$ $0.6 \mathrm{mg} / l)$. The recovery rate of $\mathrm{ALA}$ in urine was $100.3 \pm 5.5 \%$ (range $90.9-111.8 \%, n=40$ ) when $20 \mu \mathrm{l}$ of $1.5 \mathrm{mg} / \mathrm{l}$ ALA standard solution was added to each urine sample. A good recovery rate was also obtained in samples from non-lead workers. The correlation between the ALA concentrations by the M-G method ( $x \mathrm{mg} / l)$ and those by our method $(y \mathrm{mg} / l)$ was significant $(y=0.465 x+0.148, n=40, r=0.825, p<0.01)$.

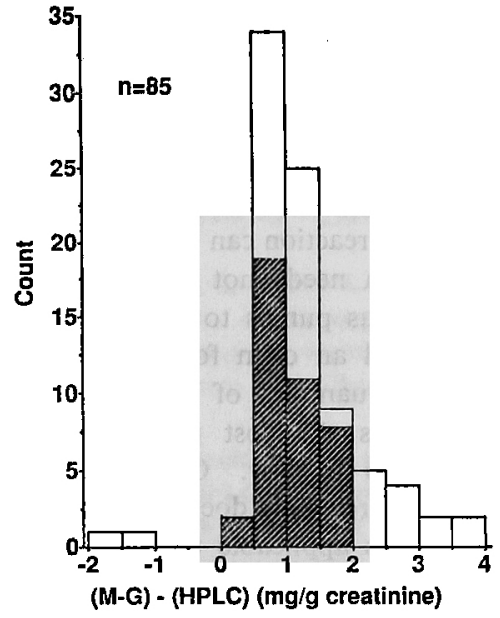

Fig. 8. Distribution of the differences between ALA concentrations ( $\mathrm{mg} / \mathrm{g}$ creatinine) by the $\mathrm{M}$ $G$ method and those by modified HPLC method. Open bars express the values found in lead workers $(n=45)$, and shaded bars the values found in non-lead workers $(n=40)$.

However, ALA concentrations obtained by this method were lower than those obtained by the M-G method in all samples from non-lead workers, and the former values were almost half of the latter, as shown in Table 3.

Although a significant correlation was found between ALA concentrations by our method and those by the M-G method in 85 workers as shown in Fig. 7, all workers, except two lead workers with high lead exposure, showed higher concentrations by the M-G method than those by our method. The difference was $1.2 \pm 0.8 \mathrm{mg} / \mathrm{g}$ creatinine (range $-1.7-3.7 \mathrm{mg} / \mathrm{g}$ creatinine, $n=85$ ), as shown in Fig. 8.

\section{DISCUSSION}

The automatic analytical system of ALA in urine has been reported by Lauwerys et al., ${ }^{\text {9) }}$ but their system has not been widely employed because of such problems as use of large scale equipment and a standard addition procedure to calculate urinary concentrations. Since HPLC has recently become a common tool for selective analysis, some analytical methods of ALA by HPLC have been reported. ${ }^{1-5,10-12)}$ These reports can be divided in two ways: One is post-column procedure ${ }^{10-12)}$ in which ALA is isolated by HPLC, followed by 
derivatization through a reaction tube and detected. The other is pre-column procedure ${ }^{1-5)}$ in which the ALA is firstly derivatized and thereafter the derivative is isolated by HPLC and measured by a detector. Since ALA is derivatized after isolation by the post-column procedure, inhibition in the process of reaction can be negligible. However, the system needs not only a complicated apparatus such as pumps to pump solutions for the reaction and an oven for the reaction tube but also large quantities of reaction solvent are consumed. Thus the cost performance of the system seems to be low. On the other hand, the pre-column procedure does not need additional apparatus and is applicable to any laboratory if the simple pre-treatment is chosen. It is stated in some reports that ALA is derivatized using formaldehyde and acetylacetone, ${ }^{1,2,13,14)}$ dansyl chloride, ${ }^{3)}$ o-phthaldialdehyde (OPA) and 2-mercaptoethanol (ME), ${ }^{4}$ or 2-amino-3-hydroxynaphthalene $(\mathrm{AHN})^{5}$ ) as derivatization reagents, then isolated by a HPLC and detected by a fluorometer. All the procedures have a sensitivity more than 10 times higher than the $M-G$ method (colorimetric method). On the other hand, the procedure using dansyl chloride ${ }^{8)}$ needs toluene extraction to eliminate obstacles at the separation of ALA by HPLC. The derivatization using OPA and $\mathrm{ME}^{4}$ ) requires a high temperature $\left(97^{\circ} \mathrm{C}\right)$ and a long period $(3 \mathrm{~h})$ for the reaction, and the AHN procedure ${ }^{5}$ needs ethyl ether extraction because AHN-ALA is unstable in aqueous solution.

The derivatization method using formaldehyde and acetylacetone $e^{1,2,14}$ is simple and forms a stable derivative without any extraction and thus the method is the most appropriate for routine analysis. However, the original Okayama meth$\mathrm{od}^{2)}$ produced relatively low recovery rate of added ALA and there was a significant negative correlation between the recovery rate and the specific gravity of the urine or urinary creatinine concentration. Tomokuni et al. ${ }^{13)}$ assumed that the low recovery was due to large quantities of components such as urea or $\mathrm{NaCl}$, but significantly negative effects of $\mathrm{NaH}_{2} \mathrm{PO}_{4}$ and $\mathrm{NH}_{4} \mathrm{Cl}$, rather than of urea or $\mathrm{NaCl}$, were observed, as shown in Fig. 4. Our modification based on the increase of acetylacetone solution from $3.5 \mathrm{ml}$ to $5 \mathrm{ml}$, the increase of formaldehyde concentration in the formalin solution from $3.1 \%$ to $9.3 \%$, and the decrease of the sample volume from $50 \mu \mathrm{l}$ to $20 \mu 1$ overcomes the negative effects of these components of derivatization (Fig. 4).

Tomokuni et al. ${ }^{13)}$ reported that the ALA derivative was unstable and its fluorescence intensity decreased by almost $50 \%$ during $3 \mathrm{~h}$ at room temperature $\left(18-21^{\circ} \mathrm{C}\right)$. On the other hand, the ALA derivative in our modified method is very stable as shown in Fig. 3, indicating that the formaldehyde concentration in this method is the most appropriate for making the fluorescent ALA derivative stable (Fig. 2). The recent paper by Tomokuni et al. ${ }^{14}$ ) reported that the stability of the fluorescent ALA derivative was affected more by light than by temperature. We did not conduct the sample treatment with particular attention to light, but since the auto-sampler we used could keep a sample in the dark and at a relatively low temperature of $15^{\circ} \mathrm{C}$, both conditions seemed to give good stability to the fluorescent ALA derivative. Under this procedure, continuous analysis using the auto-sampler can be performed after treating scores of samples at once.

Tomokuni et al. ${ }^{13)}$ reported that a fivefold dilution of the urine sample was needed to use aqueous ALA as a standard solution for a calibration curve because the intensity of the fluorescent ALA derivative in artificial urine was about $56 \%$ of that in a standard distilled water solution. In the present method, since the calibration curve made from the ALA and all the urinary components was almost the same as that from the aqueous ALA (Fig. 3), dilution of the urine was not necessary. This result agreed with the results where recoveries of added ALA were almost $100 \%$ in 85 samples and derivatization of ALA was not affected by the addition of components.

ALA concentration measured by this modified method was well correlated with that measured by the M-G method. However, urinary ALA concentrations measured by this modified method were lower than those measured by the $M-G$ method in all workers except two with high lead exposure (Fig. 8). Since the differences were not correlated with ALA concentrations and were of an almost constant value (lower than $4 \mathrm{mg} / \mathrm{g}$ creatinine), they were not considered to be byproducts or decomposition of the derivatization. Witting et al. ${ }^{10}$ ) reported that urinary ALA concentrations obtained by the HPLC/UV method were lower than those obtained by the Davis 
method $^{15}$ ) (a modification of the $M-G$ method) and that in urine samples with the Davis values below $15 \mathrm{mg} / \mathrm{l}$, the percentage of interfering compounds varied between $10 \%$ and $80 \%$ Okayama et al. ${ }^{16)}$ reported that urinary ALA concentrations obtained by the post-column HPLC fluorometric method were lower than those obtained by the Sun method ${ }^{17}$ (another modification of the M-G method). The differences between the values determined by the Sun method and those obtained by the HPLC method were not correlated with blood lead concentrations. The differences (almost two-thirds of the Sun's value) might have been caused by coexisting substances. These results agree with our results, indicating that the values determined by our modified method can give the true ALA concentrations in urine.

Urinary ALA concentrations in non-lead workers were found to be $1.1 \pm 0.4 \mathrm{mg} / \mathrm{g}$ creatinine by this modified method and this value was almost $50 \%$ of the value found by the M-G method. Okayama et al. ${ }^{16)}$ reported that urinary ALA concentrations determined by the HPLC method were lower than those determined by the colorimetric method. An increase of urinary ALA was observed in the sample with lower blood lead levels as reported earlier, and the dose-response relationship between urinary ALA and blood lead levels changed from the earlier report as determined by the colorimetric method.

In conclusion, our modified HPLC method has some advantages: (1) urinary ALA can be determined without interference from the various components of urine without using a complicated system, (2) a stable derivative of ALA can easily be made, (3) a calibration curve can be made with the aqueous standard solution, and (4) the sensitivity is very high ( $\geq 0.01 \mathrm{mg} / l$ ALA) with a wide range of linearity. Thus, this method is the most convenient for routine automated analysis. However, as ALA concentrations determined by the HPLC method were lower than those determined by the colorimetric method, it is suggested that the biological tolerance levels of urinary ALA concentrations by the HPLC method should be different from those obtained by the colorimetric method. In future studies, the effects of sex, age, and anemia on the normal range of ALA concentrations should be clarified.

\section{REFERENCES}

1) Okayama A, Lim KM, Goto S. Fluorophotometric determination of $\delta$-aminolevulinic acid in urine by reversed-phase high performance liquid chromatography. Igaku no Ayumi 1986; 139: 845846 (in Japanese).

2) Okayama A, Fujii S, Miura R. Optimized fluorometric determination of urinary $\delta$-aminolevulinic acid using pre-column derivatization, and identification of the derivative. Clin Chem 1990; 36: 1494 1497.

3) Minder EI. Measurement of 5-aminolevulinic acid by reversed phase HPLC and fluorescence detection. Clin Chim Acta 1986; 161: 11-18.

4) Meisch HU, Wannemacher B. Fluorometric determination of 5-aminolevulinic acid after derivatization with $o$-phthaldialdehyde and separation by reversed-phase high-performance liquid chromatography. Anal Chem 1986; 58: 1372-1375.

5) Meisch HU, Reinle W, Wolf U. Determination of 5-aminolevulinic acid in biological samples by highperformance liquid chromatography. Anal Biochem $1985 ; 149: 29-34$.

6) Endo Y, Okayama A, Endo G, et al. Improvement of urinary $\delta$-aminolevulinic acid determination by HPLC-fluorometry using pre-column derivatization. Jpn J Ind Health 1993; 35: 126-127 (in Japanese).

7) Mauzerall D, Granick S. The occurrence and determination of $\delta$-aminolevulinic acid and porphobilinogen in urine. J Biol Chem 1956; 219: 435446.

8) Kanai I, Kanai M, eds. Handbook of clinical chemistry, 26th ed. Tokyo: Kanehara Pub., 1972: 50-53 (in Japanese).

9) Lauwerys R, Delbroeck R, Vens M. Automated analysis of delta-aminolevulinic acid in urine. Clin Chim Acta 1972; 40: 443-447.

10) Witting U, Binding N, Muller G. Evaluation of a new specific analysis of urinary delta-aminolevulinic acid in man. Int Arch Occup Environ Health 1987 ; 59 : 375-383.

11) Okayama A. Fluorimetric determination of urinary $\delta$-aminolevulinic acid by high-performance liquid chromatography and post-column derivatization. J Chromatogr 1988; 426: 365-369.

12) Kondo M, Kimura $H$, Maekubo $T$, et al. Direct injection method for quantitation of $\delta$-aminolevulinic acid in urine by high-performance liquid chromatography. Chem Pharm Bull 1992; 40: 1948-1950.

13) Tomokuni $K$, Ichiba $M$, Hirai $Y$, et al. Optimized liquid-chromatographic method for fluorometric determination of urinary $\delta$-aminolevulinic 
acid in workers exposed to lead. Clin Chem 1987; 33: 1665-1667.

14) Tomokuni K, Ichiba M, Hirai $Y$. Measurement of urinary $\delta$-aminolevulinic acid (ALA) by fluorometric HPLC and colorimetric methods. Ind Health 1992; 30: 119-128.

15) Davis JR, Andelman SL. Urinary delta-aminolevulinic acid (ALA) levels in lead poisoning. I. A modified method for the rapid determination of urinary delta-aminolevulinic acid using disporsable ion-exchange chromatography columns. Arch Environ Health 1967 ; 15 : 53-59.

16) Okayama A, Ogawa $Y$, Miyajima $K$, et al. A new HPLC fluorimetric method to monitor urinary delta-aminolevulinic acid (ALA-U) levels in workers exposed to lead. Int Arch Occup Environ Health 1989; 61: 297-302.

17) Sun MW, Stein E, Gruen FW. A single column method for the determination of urinary $\delta$-aminolevulinic acid. Clin Chem 1969; 15: 183-189.

Reptint requests to Department of Public Health, Kansai Medical University, Fumizono-cho, Moriguchi, 570 Japan (Y. Endo). 
英文論文の和文要旨

IMPROVEMENT OF URINARY $\delta$-AMINOLEVULINIC ACID DETERMINATION

BY HPLC AND FLUORESCENCE DETECTION USING CONDENSING REACTION

WITH ACETYLACETONE AND FORMALDEHYDE

Yoko Endo, Akira OKayama, Ginji Endo, Teruko Ueda, Naoki Nakazono,

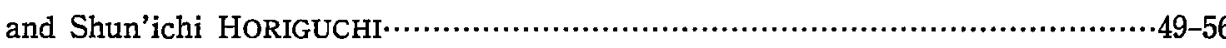

\section{アセチルアセトンとホルムアルデヒドによる縮合反応を用いた HPLC/蛍光検出法による 尿中 $\delta$-アミノレブリン酸定量法の改良}

圓藤陽子，岡山 明，圓藤吟史，上田照子，中園直樹，堀口俊一

我々は尿中デルタフミノレブリン酸（ס-ALA）をアセ チルアセトンとホルムアルデヒドを用いたプレカラム誘 導体法による HPLC-営光光度計で定量する方法が有用 であることを先に報告した。 しかしながら，その方泆に よる $\delta$-ALA の回収率は尿中共存物質の影響を強く受 け，康中 $\delta$-ALA の回収率はやや低くなっていた（84.6士 $7.6 \%, n=45)$. 本報告者は，我々は疗中 $\delta$-ALA の回収 率が泳 100\% となるように方法を改善した（101.3士 $5.5 \%, n=45)$. この改訂法は以下の方法で行った：尿 $20 \mu 1$ ，アセチルアセトン溶液（アセチルアセトン：エチ ルアルコール: $4 \mathrm{~g} / l$ の塩化ナトりウムを含有する蒸留 水 $=15: 10: 75) 5 \mathrm{ml}$, 拈よび $9.3 \%$ ホルムフルデとド 溶液 $0.45 \mathrm{ml}$ を混合し沸䮃浴で 15 分間反応させた後, 流水で冾却し，艺の $50 \mu 1$ を HPLC一蛍光光度計で測定 した（励起波長 $246 \mathrm{~nm}$ ，測定波長 $458 \mathrm{~nm}$ ). $\delta$-ALA の 保持時間は 7.3 分であった．溶液グラジェント法を用い
ることによりカラム王の上昇を避けられ，13 分間隔での 連続分析か゚可能となった。この方法によれば，種々の尿 中共存物は $\delta$-ALA 誘導体の生成に影響を与えず, 生成 された誘導体はほぼ 24 時間安定であった。この方法で 测定された尿中 $\delta$-ALA 濃度はモーゼルーグラニック (M-G) 洗で測定した值と有意に相関した $(n=85, r=$ $0.993, p<0.001)$. しかしこの方法では $\delta$-ALA の類似 物質を分離しているので, M-G 法の值よりもこの方法 による值のほうが低く，この方法による非鉛曝露作業者 40 名の尿中 $\delta$-ALA 濃度は $0.1 \sim 2.3 \mathrm{mg} / \mathrm{g}$ creatinine (1.1 $1 \pm 0.4 \mathrm{mg} / \mathrm{g}$ creatinine) と, M-G 法による濃度 (1.2 3.1 $\mathrm{mg} / \mathrm{g}$ creatinine $(2.1 \pm 0.5 \mathrm{mg} / \mathrm{g}$ creatinine) の約半分の值であった. HPLC 法による尿中 ALA 濃度 の許容値は従来の比色法による数値とは異なった值を設 する必要があると考えられる。

著者への通信先 : 圆藤陽子, 干570 大阪府守口市文園町 1 関西医科大学公秝衛生学教室

\section{EFFECTS OF REGULAR HEALTH PRACTICES ON SUBJECTIVE EVALUATION OF HEALTH}

Tomoyuki Kawada, Rosa Remy SHINmyo, and Shosuke Suzuki $\cdot .57-63$

\section{主観的健康に及ばす規則的な健康習慣の影響}

Breslow の 7 つの健康に関連する好ましい行動あるい は状態として，秋煙しないはどほどの领酒・定期的運 動・適正体重の雓持・適度な睡眠時間・朝食の掑取・間 食しない，が举げられ，これら7項目を守ることの重要 性は西洋諸国で広く認められ，またそれらに対する保健 対策も計画実施されつつある.これらの提言は，米合鼻 国で行われたコホート調查を基に策定されたすのである が， とる死亡や疾病発症に対する危険度に関しての 結果であるため, 予防医学あるいは健康増進の視点から,

\section{川田智之，新明ローザ怜美，鈴木庄亮}

身体的精神的不具合の主観的愁訴と健康習慣との関連性 については十分な検討がなされているとは言えない. 著 者らは東大式健康調查票 (THI) の 130 項目の質問中に。 Breslow の7つの健康習慣が含まれていることを確認 し，しかも本調查票が近年広く国内で使用されているこ とを踏ま元て，主観的精神身体愁訴への良い健康習慣の 影響を断面調查として実施した。

対象は東京都北区の某製造会社の男子工員および事務 員とその妻各 115 人で，夫婦共に回答した各 95 人 